\title{
PENGARUH KAPABILITAS ORGANISASI TERHADAP PERENCANAAN STRATEGIS DAN DAMPAKNYA TERHADAP KINERJA ORGANISASI DALAM PEMUNGUTAN PAJAK KENDARAAN BERMOTOR DI PROPINSI JAWA BARAT
}

\author{
Oleh : \\ Nugraha \\ (Dosen Program Studi Pendidikan Akuntansi FPEB-UPI)
}

\begin{abstract}
This paper present the result of research the Influence Of Organizational Capability as, measured by Personal Competency, Organizational Climate And Capacity, To Strategic Planning On Organizational Performance Improvement at localized vehicle taxes Collection in West Java.

The approach used in this research is explanatory survey, with Tax Service Unit of West Java Province Revenue Agency as an analysis unit. It covered all Tax Service Units of West Java Province Revenue Agency. The data of this research was collected by utilizing questionnaire and document studies then evaluated by using SEM (Structural Equation Modeling) with supported SmartPLS.

The result of this research showed that the improvement on dimensions of: (1) Officers' Competencies which consist of achievement and action, helping and public service, impact and influence, managerial, cognitive, personal effectiveness. (2) Organizational Climate which consist of task structure, reward-punishment correlation, centralization of decision, driven and achievement, training and development driven, openess-closess, ability-risk, status and spirit, recognicion and feedback, general organization flexibility and competencies (3) Organizational Capacity which consist of work capacity and working habbit factors, all dimensions have influenced to the quality of strategic planning. Another result of this research is that the improvement on these dimensions of strategic planning which consist of planning institutions, strategic philosophies research, strategic diagnosis and planning development, operational directing and organizing also influenced the performance of organization.
\end{abstract}

Key Word: Organizational Capability, Personal Competency, Organizational Climate, Performance Improvement, Taxes Collection

\section{Pendahuluan}

Salah satu pos penting pendapatan daerah adalah pos Pendapatan Asli Daerah (PAD). Menurut Ramayadi (dalam Soemitro, 2003:71), dari keempat komponen PAD, komponen pajak daerah sampai saat ini merupakan komponen terbesar yang menyumbang PAD. Besarnya kontribusi pajak daerah juga terjadi di Propinsi Jawa Barat. Dimana selama tahun 2001-2004 mencapai rata-rata 92,35\% dari PAD, atau $56,17 \%$ dari total anggaran penerimaan. Dan salah satu pos pajak daerah tersebut bersumber dari Pajak Kendaraan Bermotor (PKB \& BBNKB).

Meningat pentingnya pos ini bagi Propinsi Jawa Barat, maka selayaknya mendapat perhatian dalam pemungutanntnya. Dari hasil studi pendahuluan menunjukan jika nilai capaian realisasinya selalu di atas $100 \%$, hal ini seolah-olah menunjukan bahwa kinerja UPPD dalam pemungutan PKB \& BBNKB telah optimal. Namun jika dianalisis secara lebih mendalam, capaian realiasi yang di atas $100 \%$ ini tidak menunjukkan kinerja yang sesungguhnya. Hal ini ini disebabkan oleh adanya ketidak tepatan dalam melakukan pengukuran kinerja pemungutan pajak, yang seharusnya adalah membandingkan potensi dengan realisasinya.

Kelemahan lain dari pengukuran kinerja menggunakan perbandingan antara target dan realisasi adalah dimungkinkannya terjadi penetapan target yang dibawah potensi yang seharusnya. Dan indikasi seperti ini diduga terjadi dalam penetapan PKB \& BBNKB di Jawa Barat. Hal ini ditunjukan oleh indikasi sebagai berikut ini: a. Tingginya wajib pajak yang tidak daftar ulang. Pada tahun 2003, terdapat 467.120 wajib pajak yang tidak daftar ulang, atau mencapai angka $16 \%$ dari sekitar 2,28 juta potensi kendaraan bermotor yang ada di Jawa Barat. Dengan masih tingginya angka wajib pajak yang tidak daftar ulang sementara nilai capaian realisasi di atas target menunjukkan bahwa target yang terpungut masih di bawah potensi, dan hal ini berarti pula usaha pemungutan pajak (tax effort) lembaga UPPD masih belum optimal.

b. Hasil analisis Sunaryo, dkk (dalam Soemitro, 2003:89) menunjukkan bahwa tax ratio PKB \& BBNKB masih rendah, yaitu hanya mencapai $2,63 \%$ untuk PKB dan 3,45\% untuk BBNKB. Idealnya, dengan peranan belanja pemerintah yang tinggi dan bersarnya kontribusi PKB \& BBNKB terhadap penerimaan daerah, semestinya diikuti dengan tingginya nilai tax ratio pajak tersebut.

c. Selanjutnya, berdasarkan hasil penyusunan model penetapan target PKB \& BBNKB yang dilakukan Dispenda (2004), menunjukkan bahwa target PKB \& BBNKB masih di bawah potensi yang seharusnya.

d. Hasil studi atas wajib pajak yang menunggak oleh Dispenda Jawa Barat (2004) juga menyimpulkan bahwa sistem informasi data wajib pajak yang dipakai oleh masing-masing UPPD mengindikasikan data yang kurang akurat, atau dikenal dengan "data sampah", dan jumlahnya sebesar $23 \%-26 \%$. 
Dengan demikian dari sejumlah indikasi di atas, dapat disimpulkan bahwa capaian realisasi yang di atas target belum sepenuhnya mencerminkan kinerja lembaga tersebut. Hal ini lebih disebabkan oleh penetapan target yang di bawah potensi yang ada. Dengan kata lain, tujuan utama dari UPPD Dinas Pendapatan Propinsi Jawa Barat yang ditetapkan sebagai lembaga yang berwenang melakukan pemungutan PKB \& BBNKB belum tercapai secara optimal.

Lemahnya kinerja pemungutan PKB dan BBNKB ini diduga oleh lemahnya kecakapan dan sumber daya organisasi dalam merencanakan target, melakukan penyesuaian dengan perubahan yang terjadi di lingkungan ekternal, melakukan diagnosa terhadap pencapaian keberhasilan, fleksibilitas organisasi, dan penyelenggaraan pelayanan prima termasuk adanya komunikasi dan partisipasi antar unit kerja pun tidak terjadi.

Kemampuan organisasi itu sendiri dimaknai oleh Ansoff dan McDonnell (1990:262), sebagai kecenderungan dan kemampuan para pengelola organisasi memberi reaksi atau respon terhadap peristiwa dalam lingkungan organisasinya. Menurut Salusu (2002:303) yang sejalan dengan pendapat Ansoff dan McDonnell (1990:263), respon manajemen dapat diterangkan melalui tiga atribut kapabilitas, yaitu iklim (will to response), kompetensi (ability to response), dan kapasitas (volume of response).

Dalam hal ini, ketiga atribut kapabilitas organisasi itu di satu pihak ditentukan oleh kompetensi pengelola dan di pihak lain ditentukan oleh lingkungan organisasi tempat mereka bekerja. Dengan demikian, kapasitas dari pihak pengelola bersifat personal, sedangkan dari sudut organisasi bersifat organisasional. Kompetensi ditentukan oleh kemampuan pengelola di satu pihak, dan kemampuan sistemik organisasi di pihak lain. Iklim ditentukan oleh mentalitas/ budaya dan posisi/struktur kekuasaan organisasi. Sementara faktor ketiga yaitu kapasitas organisasi merupakan volume pekerjaan yang dapat dilakukan oleh para pegawai. Kapasitas organisasi merupakan perkalian antara kompetensi dengan jumlah jam kerja. Sehingga ukuran kapasitas organisasi dapat diukur dari produktivitas yang dihasilkan oleh organisasi dalam satuan waktu tertentu.

Sejalan dengan itu, maka persoalan rendahnya kinerja UPPD Dinas Pendapatan Propinsi Jawa Barat dalam pemungutan PKB \& BBNKB, dapat diduga dari kelemahan dari kemampuan organisasi dalam mengoptimalkan lingkungan internal organisasinya menjadi strategi pencapaian tujuan dan sasaran yang telah ditetapkan melalui perencanaan strategis. Kelemahan dalam perumusan dan implementasi strategi ini diduga sebagai akibat dari lemahnya kompetensi, iklim dan kapasitas yang ada dalam kapabilitas organisasi kelembagaan tersebut.

Pernyataan adanya kelemahan dalam kapabilitas administrasi organisasi sebenarnya sejak lama sudah diungkapkan oleh Heady (dalam Leeman, 1976:99) yang juga kembali diungkapkan oleh Kasali (2007:12-13) dengan peristilahan yang berbeda yaitu unsur pembentuk organisasi, yang mana konsep tersebut secara tersirat mengacu kepada kapabiltas organisasi dalam pandangan Salusu (2002) dan Ansoff dan McDonnell (1990). Dari uraian di atas, rumusan masalah dalam penelitian ini adalah sebagai berikut:

a. Seberapa besar pengaruh kompetensi pegawai terhadap perencanaan strategis organisasi UPPD Dinas Pendapatan Propinsi Jawa Barat.

b. Seberapa besar pengaruh iklim organisasi terhadap perencanaan strategis organisasi UPPD Dinas Pendapatan. Propinsi Jawa Barat.

c. Seberapa besar pengaruh kapasitas organisasi terhadap perencanaan strategis organisasi UPPD Dinas Pendapatan Propinsi Jawa Barat

d. Seberapa besar pengaruh perencanaan strategis terhadap kinerja organisasi UPPD Dinas Pendapatan Propinsi Jawa Barat.

\section{Landasan Teori}

Kompetensi menurut Salusu (2002:303) dan Ansoff dan McDonnell (1990:263) merupakan salah satu faktor dari kemampuan organisasi dari sisi lingkungan internal organisasi atau disebut dengan kapabilitas organisasi dalam merespon perubahan di lingkungan eksternalnya. Dalam merespon perubahan lingkungan eksternal tersebut, organisasi hendaknya memaksimalkan segenap kemampuannya, baik secara individu maupun keseluruhan, untuk mencapai tujuan dan sasaran organisasi tersebut.

Spencer dan Spencer (1993: 25-89) mengemukakan bahwa, kompetensi yang dimiliki individu dapat dibedakan menjadi enam kluster kompetensi utama, yaitu kompetensi berprestasi yang dibentuk oleh indikator orientasi prestasi, perhatian terhadap urutan, ketelitian dan kualitas, inisiatif, dan pencarian informasi; kompetensi pelayanan yang dibentuk oleh indikator pemahaman interpersonal dan orientasi kepuasan pelanggan; kompetensi mempengaruhi yang dibentuk oleh indikator mendukung dan mempengaruhi, kesadaran berorganisasi, dan membangun hubungan kerja; kompetensi manajerial yang dibentuk oleh indikator memberikan perintah dan arahan, mengembangkan orang lain, dan membangun dan memimpin tim kerja; kompetensi kognitif yang dibentuk oleh indikator berpikir analitis, berpikir konseptual, dan keahlian teknis; dan terakhir kompetensi efektivitas diri yang dibentuk oleh indikator pengendalian diri, percaya diri, dan penyesuaian diri.

Menurut Salusu (2002:303) dan Ansoff dan McDonnell (1990:263), selain kompetensi pegawai, iklim merupakan salah satu faktor dari kemampuan organisasi dari sisi lingkungan internal organisasi dalam merespon perubahan di lingkungan eksternalnya. Pierce dan Gardner (2002: 138) menyatakan bahwa iklim organisasi terdiri dari faktor-faktor seperti struktur, proses, dan organ 
orang serta keyakinannya. Disebutkan bahwa iklim organisasi adalah "the prevailing organizational condition that reflects the overall organizational tone or character". Dalam hal ini, iklim organisasi mempengaruhi dan dipengaruhi oleh sikap pegawai, motivasi pegawai, dan perilaku kerja.

Steers (1980, dalam Suryadi, 2003:86-88), yang mengutip hasil penelitian Campbell dan Beaty (1971) serta Pritchard dan Karasick (1973), mengemukakan sepuluh dimensi iklim organisasi, yakni:

a. Struktur tugas: tingkat perincian metode untuk melaksanakan tugas;

b. Hubungan imbalan-hukuman: pemberian imbalan tambahan berdasarkan prestasi dan jasa dan bukan pada senioritas, favoritisme;

c. Sentralisasi keputusan: keputusan penting dipusatkan pada manajemen atas;

d. Tekanan dan prestasi: keinginan pihak pekerja untuk melaksanakan pekerjaan dengan baik dan memberikan sumbangannya bagi organisasi;

e. Tekanan pada latihan dan pengembangan: organisasi berusaha meningkatkan prestasi individu melalui kegiatan latihan dan pengembangan yang tepat;

f. Keterbukaan versus ketertutupan: orangorang lebih suka berusaha menutupi kesalahan mereka dan menampilkan diri secara baik dari pada berkomunikasi secara bebas dan bekerjasama.

g. Kemampuan versus resiko: tekanan dalam organisasi menimbulkan perasaan kurang aman dan kecemasan pada para anggotanya;

h. Status dan semangat: perasaan umum diantara para individu bahwa organisasi merupakan tempat bekerja yang baik;

i. Pegakuan dan umpan balik: seseorang individu mengetahui apa pendapat atasannya dan manajemen mengenai pekerjaannya serta tingkat batas dukungan mereka atas dirinya;

j. Kompetensi dan keluwesan organisasi secara umum: tingkat batas organisasi mengetahui apa tujuannya dan mengejarnya secara luwes dan kreatif. Termasuk mengantisipasi masalah, mengembangkan metode baru dan mengembangkan keterampilan baru pada pekerja.

Menurut Salusu (2002:303) dan Ansoff dan McDonnell (1990:263), selain kompetensi pegawai dan iklim organisasi kapasitas organisasi merupakan salah satu faktor dari kemampuan organisasi dari sisi lingkungan internal organisasi dalam merespon perubahan di lingkungan eksternalnya. Dalam hal ini Ansoff dan McDonnell (1990:263) mendefinisikan kapasitas sebagai volume to respons.

Sejalan dengan itu, Horton Norton, et al. (2003:19) memberikan pengertian kapasitas organisasi sebagai "potential to perform -its ability to successfully apply its skill and resources to accomplish its goals and satisfy its stakeholders expectations".

Rohdelwohld (2004:3) sejalan dengan pendapat Morgan (1998:2), mengemukakan pengelompokan kapasitas organisasi kelembagaan Pemerintahan Daerah dalam tiga level yaitu: individual level, institutional/organizational level dan system level.

Dalam konteks kajian ini sesuai dengan konsep kapasitas organisasi yang diajukan oleh Ansoff dan McDonnell (1990:263) dan Salusu (2002:303) sebagai salah satu atribut dari kapabilitas organisasi diartikan sebagai "volume atau kapasitas tersedia dari organisasi dalam kemampuan memberikan respon terhadap lingkungan eksternal organisasi untuk merumuskan strategi terbaiknya". Untuk itu satuan ukuran yang dapat dipakai untuk mengukur kapasitas organisasi merujuk pada dimensi satuan waktu kapasitas kerja dan kebiasaan kerja dalam melakukan pekerjaan yang dikalikan dengan komponen kompetensi organisasi.

Menurut Mulyadi (2001:404), perencanaan strategis merupakan langkah penerjemahan strategi ke dalam sasaran-sasaran strategis yang komprehensif dan koheren. Dalam perencanaan strategis setiap sasaran strategis kemudian ditentukan ukuran pencapaian dan target yang akan diwujudkan dalam jangka waktu tertentu di masa yang akan datang. Daneke and Steiss (dalam Sutherland, 1978:428) mendefinisikan perencanaan strategis "is both a process for discovering societal goals and for translating these goals into action commitments". Bryson (2000:14) menyebutkan bahwa terdapat lima langkah pokok dalam proses perencanaan strategis, yaitu bersiap-siap, mengartikulasi visi dan misi, menilai situasi, mengembangkan strategi, tujuan, dan sasaran, dan menyelesaikan rencana tertulis.

Konsep perencanaan strategis dapat direfleksikan oleh dua aktivitas utama yaitu perumusan strategi dan implementasi strategi. Dimana untuk kedua aktivitas tersebut mengacu kepada enam dimensi yaitu: (1) pelembagaan perencanaan yang terdiri dari indikator keterlibatan pimpinan dan proses perencanaan; (2) landasan strategis yang terdiri dari indikator misi serta tujuan dan sasaran; (3) diagnosis strategis terdiri dari analisis internal dan eksternal; (4) pengembangan rencana terdiri dari indikator penggunaan diagnostic strategis dan pilihan pertimbangan; pengorganisasian terdiri dari satu indikator yaitu alokasi sumber daya; dan (6) pengarahan kegiatan operasional terdiri dari indikator pendelegasian, koordinasi, komunikasi dan motivasi (Bryson, 2000) dan (Rahmatsyah, 2004).

Kinerja adalah perilaku anggota organisasi yang mendorong perusahaan dalam mencapai tujuannya (Pierce, et al., 2002: 662). Sementara itu, pengukuran kinerja merupakan alat yang digunakan oleh manajer dalam mengukur efektifitas pencapaian tujuan dan strategi yang diharapkan (Simons, 2000: 15).

Konsep pengukuran kinerja dapat dirujuk dari Pyzdek (2000: 213) yang mengartikan pengukuran sebagai penetapan angka-angka untuk mengamati gejala sesuai dengan aturan tertentu. 
Pendapat lain, adalah dari Gary Siegel dan Helene Ramanauskas-Marconi (dalam Mulyadi, 1993:419) yang mengemukakan bahwa "penilaian kinerja adalah penentuan secara periodik efektivitas operasional suatu organisasi, bagian organisasi, dan karyawannya berdasarkan sasaran, standar, dan kriteria yang telah ditetapkan sebelumnya."

Berkenaan dengan tujuan pengukuran kinerja, Kaplan dan Norton (2000: 128) berpendapat bahwa "Tujuan dari setiap sistem pengukuran seharusnya adalah untuk memotivasi semua manajer dan pekerja agar melaksanakan strategi organisasi dengan berhasil". Organisasi yang dapat menerjemahkan strategi ke dalam sistem pengukuran akan jauh lebih mampu melaksanakan strategi karena dapat mengkomunikasikan tujuan dan sasarannya, dan pendekatan itu dikenal dengan balanced scorecard.

Whittaker (1995:36) menyatakan bahwa: "Pengukuran kinerja instansi pemerintah sebagai alat manajemen yang dipergunakan untuk meningkatkan kualitas pengambilan keputusan dan akuntabilitas dalam rangka menilai keberhasilan atau kegagalan pelaksanaan kegiatan atau program sesuai dengan sasaran dan tujuan yang telah ditetapkan". Menurut Hatry (dalam Nasir, dkk., 2003:37) bahwa permasalahan utama dalam pengukuran kinerja adalah proses pertanggungjawaban kepada stakeholders. Sehingga model pengukuran kinerja yang paling objektif adalah pengukuran kinerja yang melibatkan kepentingan stakeholders.

Dengan demikian, model pengukuran kinerja dengan menggunakan empat perspektif sebagaimana diajukan oleh Kaplan dan Norton yang sebelumnya diperuntukkan untuk sektor bisnis, dalam kepentingan ini dapat diadopsi oleh untuk sektor publik, dengan melakukan sejumlah penyesuaian, terutama dalam penentuan indikator dalam masing-masing perspektif. Sebab dalam pengukuran kinerja yang berbasis Balanced Scorecard ini dapat diyakini memiliki nilai objektivitas yang tinggi, khususnya dalam mengukur kinerja organisasi publik secara komprehensif.

Dalam bagian lain Suharyani dkk (dalam Natsir, dkk, 2003:55) bahkan menyebutkan secara tegas bahwa sistem penilaian yang dipandang lebih komprehensif sebagai metode yang mengungkapkan pentingnya penilaian kinerja organisasi baik dari sisi keuangan maupun non keuangan adalah pendekatan balanced scorecard.

Balanced scorecard sebagai suatu sistem pengukuran kinerja dapat digunakan sebagai alat pengendalian, analisis, dan merevisi strategi organisasi. Dewasa ini, balanced scorecard bukan hanya digunakan oleh organisasi bisnis tetapi juga oleh organisasi publik. Dalam hal ini, balanced scorecard dapat membantu organisasi publik dalam mengendalikan keuangan dan mengukur kinerja organisasi (Modell dalam Imelda, 2007: 107).

Perbedaan mendasar antara organisasi bisnis dan organisasi publik adalah organisasi bisnis berorientasi profit sedangkan organisasi publik berorientasi non-profit. Imelda (2007: 107) yang mengacu pada Averson (1999), menegaskan bahwa kesejajaran atau alignment antara organisasi bisnis dan organisasi publik dapat dilihat dari segi tujuan strategis, tujuan financial, stakeholders, dan outcome.

Sejalan dengan itu, maka dalam pengukuran kinerja organisasi UPPD Dinas Pendapatan Propinsi Jawa Barat dalam pemungutan Pajak Kendaraan Bermotor dan Bea Balik Nama Kendaraan Bermotor akan mempergunakan pendekatan balanced scorecard sebagaimana diajukan oleh Kaplan dan Norton, (2000) serta Mulyadi (2001).

Berdasarkan kerangka pemikiran dan paradigma penelitian di atas, maka selanjutnya dapat ditarik hipotesis-hipotesis sebagai berikut:

a. Besarnya pengaruh kompetensi pegawai terhadap perencanaan strategis ditentukan oleh: dimensi kompetensi berprestasi dan bertindak, kompetensi pelayanan, kompetensi mempengaruhi orang lain, kompetensi manajerial, kompetensi keahlian dan kompetensi efektivitas diri.

b. Besarnya pengaruh iklim organisasi terhadap perencanaan strategis ditentukan oleh: dimensi struktur tugas, hubungan imbalan-hukuman, sentralisasi keputusan, tekanan dan prestasi, tekanan pada latihan dan pengembangan, keterbukaan-ketertutupan, kemampuan-resiko, status dan semangat, pengakuan dan umpan balik, kompetensi dan keluwesan organisasi secara umum

c. Besarnya pengaruh kapasitas organisasi terhadap perencanaan strategis ditentukan oleh dimensi kapasitas kerja dan kebiasaan kerja.

d. Besarnya pengaruh perencanaan strategis terhadap kinerja organisasi ditentukan oleh: dimensi pelembagaan perencanaan, pengkajian landasan strategis, diagnosis strategis (situasi) dan pengembangan rencana serta dimensi pengorganisasian dan pengarahan kegiatan operasional

\section{Metode Penelitian}

Pajak Kendaraan Bermotor dan Bea Balik Nama Kendaraan Bermotor, yang selanjutnya disebut PKB \& BBNKB merupakan salah satu pajak yang dipungut oleh Pemerintah Propinsi dengan lokasi pemungutan di Kabupaten/Kota. Sehingga untuk melaksanakan fungsi pelayanan pendapatan tersebut telah dibentuk 31 (tiga puluh satu) unit pelayanan pendapatan daerah (UPPD) yang tersebar di seluruh Kabupaten/Kota yang ada di Jawa Barat. Tujuan utama dari kelembagaan UPPD ini untuk meningkatkan kualitas pelayanan kepada masyarakat serta sekaligus menjamin keberhasilan dalam pelaksanaan fungsi pemungutan Pajak di Daerah.

Variabel yang dikaji dalam penelitian ini terdiri dari variabel bebas (independent variable) yaitu kompetensi pegawai (Variabel $X_{1}$ ), iklim organisasi $\left(X_{2}\right)$, kapasitas organisasi $\left(X_{3}\right)$, serta Perencanaan Strategis $(Y)$. Sedangkan yang menjadi variabel terikat (dependent variable) adalah Kinerja Organisasi (Z). 
Metode analisis yang akan digunakan dalam penelitian ini adalah Structural Equation Modeling (SEM), dan pada umumnya SEM menggunakan pendekatan Linear Structural Relationship (LISREL) dengan metode Maksimum Likelihood sebagai pendugaan parameternya. Namun, karena banyaknya sampel penelitian hanya 31 , sedangkan dalam LISREL sampel Rule of Thumb yang dibutuhkan paling sedikit adalah 100 sehingga LISREL tidak dapat digunakan sebagai alat untuk menduga parameter-parameter dalam model di atas. Salah satu metode yang dapat digunakan adalah dengan menggunakan Metode Partial Least Square (PLS) digabung dengan metode Resampling untuk memperbanyak ukuran sampel.

Pendugaan dengan metode PLS dilakukan dengan menggunakan software VisualPLS. Metode Partial Least Square. Metode ini dikembangkan sebagai solusi dari pelanggaran-pelanggaran asumsi yang dibutuhkan pada saat pemodelan persamaan structural dengan menggunakan LISREL.

\section{Hasil Penelitian dan Pembahasan}

Adapun analisis validasi variabel laten eksogen dan endogen seluruh variable penelitian disajikan pada tabel berikut ini.

Tabel 1

Analisis Validasi Variabel Laten Eksogen dan Endogen

\begin{tabular}{|c|c|c|c|c|c|}
\hline No & $\begin{array}{c}\text { Variabel manifes dari variabel laten } \\
\text { Kompetensi Pegawai }\end{array}$ & $\begin{array}{l}\text { Estimasi } \\
\text { Parameter }\end{array}$ & $\mathbf{R}^{2}$ & $\begin{array}{l}\text { Error } \\
\text { Varians } \\
\end{array}$ & t-hitung \\
\hline 1 & $\begin{array}{l}\text { Kompetensi Berprestasi dan } \\
\text { Bertindak }\end{array}$ & 0,8098 & 0,6558 & 0,1086 & 7,4538 \\
\hline 2 & Kompetensi Pelayanan & 0,4590 & 0,2107 & 0,2091 & 2,1947 \\
\hline 3 & $\begin{array}{l}\text { Kompetensi Mempengaruhi } \\
\text { Orang Lain }\end{array}$ & 0,5301 & 0,2810 & 0,1983 & 2,6735 \\
\hline 4 & Kompetensi Manajerial & 0,8027 & 0,6443 & 0,0624 & 12,858 \\
\hline 5 & Kompetensi Keahlian & 0,6864 & 0,4711 & 0,0876 & 7,8349 \\
\hline 6 & Efektivitas Diri & 0,7800 & 0,6084 & 0,0881 & 8,8502 \\
\hline No & $\begin{array}{l}\text { Variabel manifes dari variabel laten } \\
\text { Iklim Organisasi }\end{array}$ & $\begin{array}{l}\text { Estimasi } \\
\text { Parameter }\end{array}$ & $\mathbf{R}^{2}$ & $\begin{array}{l}\text { Error } \\
\text { Varlans } \\
\end{array}$ & thitung \\
\hline 1 & Struktur Tugas $\quad \mathrm{X}_{21}$ & 0,5655 & 0,3198 & 0,1435 & 3.9397 \\
\hline 2 & Hubungan Imbalan-Hukuman & 0,7202 & 0,5187 & 0,1365 & 5.2750 \\
\hline 3 & Sentralisasi Keputusan & 0,7165 & 0,5134 & 0,0845 & 8.4749 \\
\hline 4 & Tekanan dan Prestasi & 0,4775 & 0,2280 & 0,1468 & 3.2521 \\
\hline 5 & $\begin{array}{l}\text { Tekanan pada Latihan dan } \\
\text { Pengembangan }\end{array}$ & 0,7254 & 0,5262 & 0,0976 & 7.4349 \\
\hline 6 & $\begin{array}{l}\text { Keterbukaan versus } \\
\text { Ketertutupan }\end{array}$ & 0,4417 & 0,1951 & 0,2032 & 2.1741 \\
\hline 7 & Kemampuan versus Risiko & 0,6178 & 0,5341 & 0,0977 & 7.4824 \\
\hline 8 & Status dan Semangat & 0,6353 & 0,3817 & 0,1579 & 3.9120 \\
\hline 9 & Pengakuan dan Umpanbalik & 0,5012 & 0,2512 & 0,1861 & 2.6934 \\
\hline 10 & $\begin{array}{l}\text { Kompetensi dan Keluwesan } \\
\text { Organisasi Secara Umum } \quad X_{210}\end{array}$ & 0,6583 & 0,4334 & 0,0783 & 8.4042 \\
\hline No & $\begin{array}{c}\text { Variabel manifes dari variabel laten } \\
\text { Kapasitas Organisasi }\end{array}$ & $\begin{array}{l}\text { Estimasi } \\
\text { Parameter }\end{array}$ & $R^{2}$ & $\begin{array}{l}\text { Error } \\
\text { Varians }\end{array}$ & thitung \\
\hline 1 & Kapasitas Kerja & 0,8050 & $\begin{array}{c}0,6480 \\
3\end{array}$ & 0,0752 & 10.327 \\
\hline 2 & Kebiasaan Kerja & 0,8734 & $\begin{array}{c}0,7628 \\
3 \\
\end{array}$ & 0,0732 & 12.9372 \\
\hline No & $\begin{array}{c}\text { Variabel manifes dari variabel laten } \\
\text { Perencanaan Strategis }\end{array}$ & $\begin{array}{l}\text { Estimasi } \\
\text { Parameter }\end{array}$ & $R^{2}$ & $\begin{array}{l}\text { Error } \\
\text { Varians }\end{array}$ & thitung \\
\hline 1 & Pelembagaan Perencanaan & 0,6712 & 0,4505 & 0,1101 & 6.0961 \\
\hline 2 & Landasan Strategis & 0,4714 & 0,2222 & 0,1911 & 2.4664 \\
\hline 3 & Diagnosis Strategis (Situasi) & 0,6706 & 0,4497 & 0,1034 & 6.4852 \\
\hline 4 & Pengembangan Rencana & 0,5535 & 0,3064 & 0,1010 & 5.4800 \\
\hline 5 & Pengorganisasian & 0,6760 & 0,4570 & 0,1284 & 5.2657 \\
\hline 6 & $\begin{array}{l}\text { Pengarahan Kegiatan } \\
\text { Operasional }\end{array}$ & 0,8493 & 0,7213 & 0,0348 & 24.393 \\
\hline No & $\begin{array}{c}\text { Variabel manifes dari variabel laten } \\
\text { Kinerja Organisasi }\end{array}$ & $\begin{array}{l}\text { Estimasi } \\
\text { Parameter }\end{array}$ & $\mathbf{R}^{2}$ & $\begin{array}{l}\text { Error } \\
\text { Varians }\end{array}$ & t-hitung \\
\hline 1 & Perspektif Keuangan & 0,7400 & 0,5520 & 0,1442 & 5.1514 \\
\hline 2 & Perspektif Konsumen & 0,8080 & 0,6498 & 0,1325 & 6.0842 \\
\hline 3 & Perspektif Proses Internal & 0,8031 & 0,6450 & 0,0749 & 10,7199 \\
\hline 4 & $\begin{array}{l}\text { Perspektif Pembelajaran dan } \\
\text { Pertumbuhan Organisasi }\end{array}$ & 0,8639 & 0,7453 & 0,0571 & 15.122 \\
\hline
\end{tabular}




\subsection{Pengujian Data Dan Uji Hipotesis}

Hasil pengolahan data dengan menggunakan program LISREL ditunjukkan pada gambar berikut:

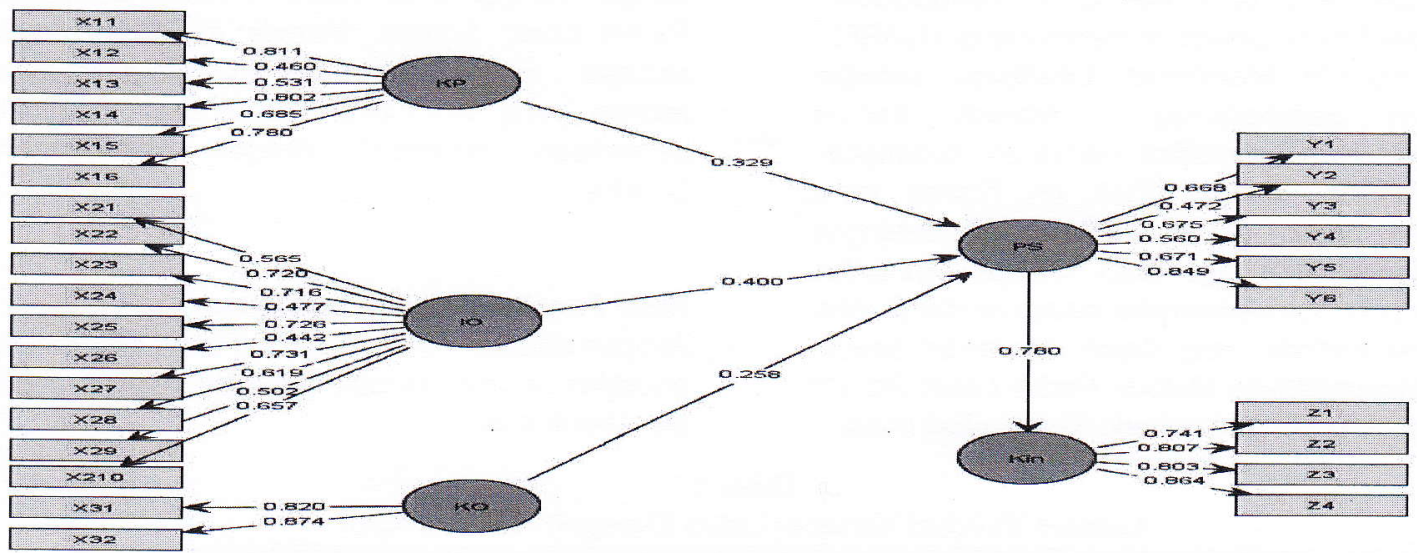

Gambar 1

Model Dasar dan Struktural Hubungan Kompetensi Pegawai , Iklim Organisasi dan Kapasitas dengan Perencanaan Strategis dan Kinerja Organisasi UPPD Dinas Pendapatan Propinsi Jawa Barat

Adapun secara sederhana, model strukturalnya dapat digambarkan pada gambar berikut.

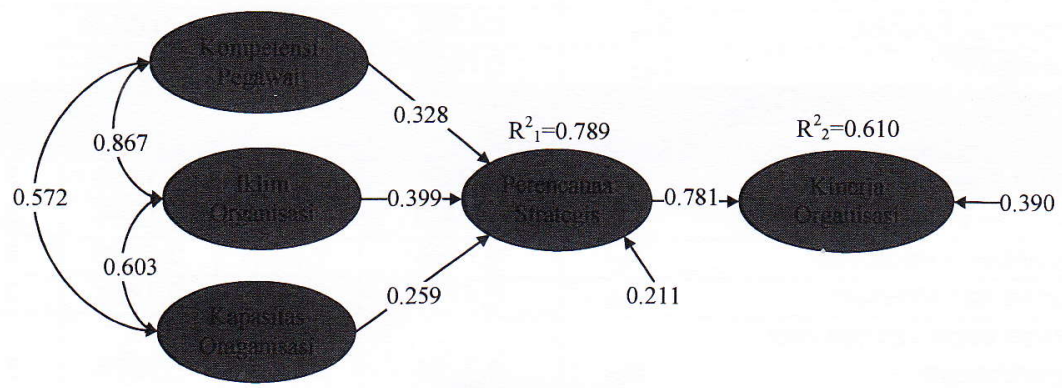

Gambar 2

Model Struktural Pengaruh Kompetensi Pegawai, Iklim Organisasi, Kapasitas Organisasi dalam Perencanaan Strategis Terhadap Kinerja Organisasi

Dilihat dari model struktural, semua variabel eksogen memberikan pengaruh siginifikan terhadap perencanaan strategi dengan efek langsung nya masing-masing sebesar 0,328 untuk variabel kompetensi organisasi, 0,399 untuk iklim organisasi, dan 0,295 untuk kapasitas organisasi koefisien determinasi dari ketiga variabel ini sebesar 0,789 atau $78,9 \%$ dengan total pengaruh variabel lain sebesar 0,211 atau $21,1 \%$ merupakan faktorfaktor lain yang tidak terjelaskan oleh model ini. Koefisein determinasi yang lebih besar dari 0,5 ini menunjukkan bahwa model struktur pertama fit dengan data atau dengan kata lain, kajian yang dilakukan selaras dengan dasar teori yang digunakan. Koefisien jalur variabel endogen perencanaan organisasi terhadap kinerja organisasi sebesar 0,781 dengan koefisien deteminasi sebesar 0,610 atau $61 \%$ dengan pengaruh faktor lain sebesar $39 \%$. Ini mengindikasikan model struktur kedua juga fit dengan data.

Selain koefisien determinasi untuk mengetahui bahwa model yang diajukan valid, dapat juga digunakan koefisien reliabilitas konstruk sebagai berikut :
Tabel 2

Reliabilitas Model

\begin{tabular}{|l|c|c|c|}
\hline \multicolumn{1}{|c|}{ Construct } & $\begin{array}{c}\text { Composite } \\
\text { Reliability }\end{array}$ & $\sqrt{A V E}$ & $\begin{array}{c}\text { Cronbach } \\
\text { Alpha }\end{array}$ \\
\hline $\begin{array}{l}\text { Kompetensi } \\
\text { organisasi }\end{array}$ & 0,840991 & 0,691764 & 0,793917 \\
\hline Iklim Organisasi & 0,861341 & 0,624621 & 0,826163 \\
\hline $\begin{array}{l}\text { Kapasitas } \\
\text { Organisasi }\end{array}$ & 0,839243 & 0,646730 & 0,857541 \\
\hline $\begin{array}{l}\text { Perencanaan } \\
\text { Organisasi }\end{array}$ & 0,816992 & 0,659166 & 0,727449 \\
\hline $\begin{array}{l}\text { Kinerja } \\
\text { Organisasi }\end{array}$ & 0,880103 & 0,804960 & 0,793633 \\
\hline
\end{tabular}

Sumber: data diolah, 2007

Dari tabel 4.2 di atas terlihat bahwa semua laten memiliki koefisien reliabilitas yang lebih besar dari 0,5 sehingga model dapat dinyatakan fit dengan data.

Hasil model struktural pertama menunjukkan bahwa variabel yang paling bepengaruh terhadap perencanaan organisasi adalah variabel iklim organisasi, kemudian dikuti oleh kompetensi organisasi dan terakhir adalah kapasitas organisasi.

Sementara ringkasan hasil komputasi statistik SEM Model Struktural ini dengan ukuran sampel sebanyak 31 (tiga puluh satu) responden disajikan pada table berikut : 
Tabel 3

Ringkasan Hasil Komputasi Statistik SEM Model Struktural

\begin{tabular}{|c|c|c|c|c|c|}
\hline \multicolumn{2}{|c|}{ Persamaan Struktural } & \multirow{2}{*}{$\begin{array}{l}\text { Koefisien } \\
\text { Jalur } \\
\text { (Distandarkan) }\end{array}$} & \multirow[b]{2}{*}{$\begin{array}{l}\text { Nilai } \\
\text { t-hitung }\end{array}$} & \multirow{2}{*}{$\begin{array}{c}\text { Hasil Uji } \\
(\alpha= \\
0,05) \\
\end{array}$} & \multirow[b]{2}{*}{$R^{2}$} \\
\hline $\begin{array}{c}\text { Variabel Laten } \\
\text { Endogen }\end{array}$ & $\begin{array}{c}\text { Variabel Laten } \\
\text { Eksogen }\end{array}$ & & & & \\
\hline \multirow{3}{*}{$\begin{array}{l}\text { Perencanaan } \\
\text { Strategis }\end{array}$} & Kompetensi Pegawai & 0,3280 & 2,304 & Signifikan & \multirow{3}{*}{0,789} \\
\hline & Iklim Organisasi & 0,3990 & 2,322 & Signifikan & \\
\hline & Kapasitas Organisasi & 0,2590 & 2,531 & Signifikan & \\
\hline Kinerja Organisasi & Perencanaan Strategis & 0,7810 & 14,533 & Signifikan & 0,610 \\
\hline
\end{tabular}

Sumber: Hasil Pengolahan Data, 2007

Adapun gambaran dekomposisi pengaruh kompetensi pegawai, iklim organisasi dan kapasitas organisasi dalam perencanaan strategis pada UPPD Dinas Pendapatan Propinsi Jawa Barat secara langsung maupun tak-langsung disajikan dalam tabel 4

Tabel 4

Dekomposisi Pengaruh Langsung dan

Tak-Langsung Kompetensi Pegawai, Iklim Organisasi dan Kapasitas Organisasi Terhadap Perencanaan Strategis

\begin{tabular}{|l|c|c|c|}
\hline \multirow{2}{*}{ Variabel } & \multicolumn{2}{|c|}{ Pengaruh } & \multirow{2}{*}{ Total } \\
\cline { 2 - 3 } & Langsung & Tak- \\
Ingsng & \\
\hline $\begin{array}{l}\text { Kompetensi } \\
\text { Pegawai }\end{array}$ & 0,3280 & - & 0,3280 \\
\hline $\begin{array}{l}\text { Iklim } \\
\text { Organisasi }\end{array}$ & 0,3990 & - & 0,3990 \\
\hline $\begin{array}{l}\text { Kapasitas } \\
\text { Organisasi }\end{array}$ & 0,2590 & - & 0,2590 \\
\hline \multicolumn{3}{|c|}{ Total } & 0,9860 \\
\hline
\end{tabular}

Sumber: Hasil Pengolahan Data, 2007

Mengacu kepada table 3 dan 4 di atas, maka hipotesis pertama, kedua da ketiga dalam penelitian ini dapat diterima. Sementara untuk menguji hipotesis keempat perlu digambarkan dulu dekomposisi pengaruh secara langsung maupun tak-langsung dari perencanaan strategis terhadap kinerja organisasi pada UPPD Dinas Pendapatan Propinsi Jawa Barat.

Tabel 5

Dekomposisi Pengaruh Langsung dan TakLangsung Perencanaan Strategis Terhadap Kinerja Organisasi

\begin{tabular}{|l|c|c|c|}
\hline \multirow{2}{*}{ Variabel } & \multicolumn{2}{|c|}{ Pengaruh } & \multirow{2}{*}{ Total } \\
\cline { 2 - 4 } & Langsung & $\begin{array}{c}\text { Tak- } \\
\text { Ingsng }\end{array}$ & \\
\hline $\begin{array}{l}\text { Kompetensi } \\
\text { Pegawai }\end{array}$ & - & 0,2562 & 0,2562 \\
\hline $\begin{array}{l}\text { Iklim } \\
\text { Organisasi }\end{array}$ & - & 0,3116 & 0,3116 \\
\hline $\begin{array}{l}\text { Kapasitas } \\
\text { Organisasi }\end{array}$ & - & 0,2023 & 0,2023 \\
\hline $\begin{array}{l}\text { Perencanaan } \\
\text { Strategis }\end{array}$ & 0,7810 & - & 0,7810 \\
\hline
\end{tabular}

Sumber: Hasil Pengolahan Data, 2007

Dari table 3 dan 5 di atas dapat ditunjukan bahwa hipotesis keempat dari penelitian ini dapat diterima.
Sejalan dengan hasil penelitian dan uji hipotesis di atas, maka dapat dinyatakan bahwa ketiga komponen dari kapabilitas organisasi yang terdiri kompetensi pegawai, iklim organisasi dan kapasitas organisasi dengan masing-masing dimensi dapat dinyatakan secara empirik mampu mempengaruhi perencanaan strategis yang dilaksanakan pada UPPD Dinas Pendapatan Propinsi Jawa Barat. Koefisien jalur kompetensi pegawai, iklim organisasi, dan kapasitas organisasi terhadap perencanaan strategis masing-masing adalah sebesar 0,$328 ; 0,399$; dan 0,259 . Hal ini menunjukkan bahwa pengaruh yang paling besar terhadap perencanaan strategis adalah Iklim Organisasi, diikuti dengan kompetensi pegawai, dan kapasitas organisasi.

Hasil temuan tersebut sejalan dengan pendapat yang diajukan oleh Salusu (2002:303) dan Ansoff dan McDonnell (1990:263), yang mengatakan bahwa faktor iklim organisasi, diikuti kompetensi pegawai dan selanjutnya kapasitas organisasi sebagai faktor dari kapabilitas organisasi (faktor kekuatan dan kelemahan dalam lingkungan internal organisasi) dalam merespon perubahan lingkungan eksternal organisasi untuk merumuskan dan mengimplementasikan strategi.

Kondisi empirik ini juga sejalan dengan pendapat Pietersen (2002:63) yang menggambarkan tentang faktor yang mempengaruhi strategi dalam perencanaan strategis adalah (1) orang yang meliputi kompetensi dan motivasi; (2) struktur dan proses organisasi yang direfleksikan dengan design organisasi, pengambilan keputusan dan sistem informasi; (3) budaya organisasi dan; (4) sistem pengukuran kinerja dan penghargaan. Point kedua, ketiga dan keempat dari Pietersen tersebut dalam kajian ini merupakan dimensi dari iklim organisasi. Dengan demikian hasil kajian ini menguatkan kajian yang dilakukan oleh A. Kartiwa (2001), Sjarif (2003), Majidah (2004), serta Rahayu (2006) tentang pentingnya komponen internal organisasi dalam perencanaan strategis dalam menunjang kinerja organisasi.

Sesuai dengan hasil penelitian di atas maka dapat dinyatakan bahwa masalah utama UPPD Dinas Pendapatan Propinsi Jawa Barat sebagaimana organisasi publik lainnya di negara berkembang seperti diungkapkan oleh Heady (dalam Leemans, 1976:99) dan juga Kasali (2007:12-13) adalah pada aspek kapabilitas organisasi ini. Sehingga seluruh penataan dalam manajemen pemerintahan dapat difokuskan pada aspek pengembangan kapabilitas ini 
Kapabilitas organisasi itu sendiri menurut Salusu (2002:303) dan Ansoff dan McDonnell (1990:263) adalah menyangkut kesiapan kondisi internal organisasi dalam merespon perubahan yang terjadi di luar lingkungan organisasinya. Kesiapan ini terdiri meliputi tiga kesiapan yaitu: (1) kemauan untuk memberikan respon terhadap perubahan dalam lingkungan, yang lebih dikenal dengan istilah iklim (will to response); (2) kemampuan untuk memberi respon, yang lebih dikenal dengan kompetensi (ability to response); (3) volume pekerjaan yang dapat dilakukan, yang lebih dikenal dengan kapasitas (volume of response).

Selain itu, dapat dijelaskan pula bahwa tingginya pengaruh iklim organisasi dalam perencanaan strategis pada UPPD Dinas Pendapatan Propinsi Jawa Barat mengindikasikan bahwa iklim organisasi merupakan komponen kapabilitas organisasi yang memiliki kontribusi terbesar dalam perencanaan strategis. Iklim organisasi yang meliputi struktur tugas, pola imbalan, proses pengambilan keputusan, fleksibilitas organisasi termasuk sistem karir dan kesempatan pendidikan merupakan aspek yang memiliki kontribusi yang cukup besar terhadap perencanaan strategis.

Dengan adanya hasil penelitian ini menunjukkan ada kesesuaian dengan pendapat Lewin (dalam steers, 1985:120), Greenberg and Baron (2003:83) serta Gibson (1973:242) tentang pentingnya iklim organisasi dalam perubahan perilaku organisasi. Perencanaan strategis itu sendiri dipahami oleh Greenberg and Baron (2003:586) sebagai salah satu pendekatan yang dapat dilakukan dalam perubahan perilaku organisasi.

Lebih jauh dikatakan oleh Gibson (1973:242) bahwa iklim sangat erat kaitannya dengan seseorang yang melaksanakan tugas. Iklim sebagai faktor situasi dimana individu bekerja jika disinergikan dengan kemampuan individu (kompetensi) akan menghasilkan kualitas pekerjaan individu yang bersangkutan. Dengan demikian penciptaan iklim organisasi yang didukung oleh kompetensi pegawai serta kapasitas organisasi untuk mendukung pencapaian tujuan organisasi memiliki landasan yang kuat untuk terus diupayakan.

Selanjutnya dengan mengacu kepada hasil pembahasan sebelumnya tentang pengaruh kompetensi pegawai, iklim organisasi dan kapasitas organisasi terhadap perencanaan strategis khususnya pada UPPD Dinas Pendapatan Propinsi Jawa Barat dan umumnya pada kelembagaan pemerintah daerah, dapat ditunjukkan bahwa strategi pengembangan yang dapat dikembangkan adalah sebagai berikut:

Pertama, aspek-aspek dalam kompetensi pegawai yang memiliki peluang untuk dikembangkan adalah peningkatan orientasi pegawai melalui penetapan acuan kinerja (Faure and Faure, 1999) (Gaspersz, 2001:58-59) (Ismail, 2007:45); penetapan formalisasi atau standarisasi capaian kinerja (Robbins, 1995: 103); perumusan standar dan pedoman kinerja (Mustopadidjaja, 2000:9-10); dan peningkatan kesadaran pegawai akan pelayanan sebagai salah satu prinsip utama dalam penyelenggaraan pemerintahan (Robbins, 1995:4344) (Gaspersz, 2001: 69-70);

Kedua, aspek-aspek dalam iklim organisasi yang memiliki peluang untuk dikembangkan adalah pengembangan sistem rekruitmen dan karir yang didasarkan pada sistem merit (Said, 2007:106-108); melakukan perubahan perilaku dan budaya aparatur yang lebih terbuka dan berorientasi pada nilai-nilai keadilan (Mustopadidjaja, 2000:10); melakukan reformasi birokrasi menuju manajemen modern (A. Kartiwa, 2004:24); mengembangkan birokrasi wirausaha (Said, 2007:320-332).

Ketiga, sementara untuk kapasitas organisasi sesuai dengan pendapat yang diajukan oleh Salusu (2002:303) dan Ansoff dan McDonnell (1990:263) bahwa satuan ukuran yang dapat dipakai untuk mengukur kapasitas organisasi merujuk pada satuan waktu kapasitas kerja dan kebiasaan dalam melakukan pekerjaan yang dikalikan dengan komponen kompetensi pegawai dan iklim organisasi, maka seluruh upaya pada aspek kompetensi pegawai dan iklim organisasi keseluruhannya secara langsung akan memberikan kontribusi dalam upaya peningkatan kapasitas organisasi,

Selain itu dapat dijelaskan bahwa bahwa kapabilitas organisasi UPPD Dinas Pendapatan Propinsi Jawa Barat saat ini masih lemah. Kelemahan kapabilitas atau daya respon internal organisasi jika dianalisis lebih jauh kesemuanya bermuara pada ketidakmampuan organisasi dalam melaksanakan ketentuan formal organisasi untuk berjalan sebagaimana seharusnya sesuai dengan ketentuan yang telah ditetapkan. Hasil survey pendahuluan dan dilanjutkan dengan pengamatan di Pemerintah Daerah menunjukkan bahwa ketetapan organisasi untuk sebagian besar pengelolaan organisasi sudah mampu dirumuskan. Termasuk perumusan tentang standar capaian kinerja, pedoman kerja (SOP) dan sejumlah mekanisme hubungan kerja lainnya. Namun, dalam implementasinya seringkali terjadi penyimpangan yang dipicu oleh kepentingan informal dari sebagian anggota organisasi. Dan yang lebih mengkhawatirkan penyimpangan dari ketentuan ini dilakukan secara kelembagaan artinya dilakukan dengan terbuka, namun dalam proses administrasi pertanggungjawaban kesemuanya dikembalikan seolah-olah itu mengacu kepada ketentuan yang ada.

Munculnya perilaku organisasi yang penuh dengan kepura-puraan, tidak lepas dari dominasi kepentingan informal dalam proses pengambilan keputusan. Kekuasaan dalam proses pengambilan keputusan organisasi lebih banyak bersumber dari kepentingan informal dibandingkan dengan kekuasaan formal atau kewenangan anggota organisasi tersebut.

Proses keorganisasian dan pengambilan keputusan yang tidak didasarkan pada kelembagaan formal telah mereduksi kewenangan jabatan formal yang dimiliki organisasi tersebut. Akibatnya antara 
Kapabilitas organisasi itu sendiri menurut Salusu (2002:303) dan Ansoff dan McDonnell (1990:263) adalah menyangkut kesiapan kondisi internal organisasi dalam merespon perubahan yang terjadi di luar lingkungan organisasinya. Kesiapan ini terdiri meliputi tiga kesiapan yaitu: (1) kemauan untuk memberikan respon terhadap perubahan dalam lingkungan, yang lebih dikenal dengan istilah iklim (will to response); (2) kemampuan untuk memberi respon, yang lebih dikenal dengan kompetensi (ability to response); (3) volume pekerjaan yang dapat dilakukan, yang lebih dikenal dengan kapasitas (volume of response).

Selain itu, dapat dijelaskan pula bahwa tingginya pengaruh iklim organisasi dalam perencanaan strategis pada UPPD Dinas Pendapatan Propinsi Jawa Barat mengindikasikan bahwa iklim organisasi merupakan komponen kapabilitas organisasi yang memiliki kontribusi terbesar dalam perencanaan strategis. Iklim organisasi yang meliputi struktur tugas, pola imbalan, proses pengambilan keputusan, fleksibilitas organisasi termasuk sistem karir dan kesempatan pendidikan merupakan aspek yang memiliki kontribusi yang cukup besar terhadap perencanaan strategis.

Dengan adanya hasil penelitian ini menunjukkan ada kesesuaian dengan pendapat Lewin (dalam steers, 1985:120), Greenberg and Baron (2003:83) serta Gibson (1973:242) tentang pentingnya iklim organisasi dalam perubahan perilaku organisasi. Perencanaan strategis itu sendiri dipahami oleh Greenberg and Baron (2003:586) sebagai salah satu pendekatan yang dapat dilakukan dalam perubahan perilaku organisasi.

Lebih jauh dikatakan oleh Gibson (1973:242) bahwa iklim sangat erat kaitannya dengan seseorang yang melaksanakan tugas. Iklim sebagai faktor situasi dimana individu bekerja jika disinergikan dengan kemampuan individu (kompetensi) akan menghasilkan kualitas pekerjaan individu yang bersangkutan. Dengan demikian penciptaan iklim organisasi yang didukung oleh kompetensi pegawai serta kapasitas organisasi untuk mendukung pencapaian tujuan organisasi memiliki landasan yang kuat untuk terus diupayakan.

Selanjutnya dengan mengacu kepada hasil pembahasan sebelumnya tentang pengaruh kompetensi pegawai, iklim organisasi dan kapasitas organisasi terhadap perencanaan strategis khususnya pada UPPD Dinas Pendapatan Propinsi Jawa Barat dan umumnya pada kelembagaan pemerintah daerah, dapat ditunjukkan bahwa strategi pengembangan yang dapat dikembangkan adalah sebagai berikut:

Pertama, aspek-aspek dalam kompetensi pegawai yang memiliki peluang untuk dikembangkan adalah peningkatan orientasi pegawai melalui penetapan acuan kinerja (Faure and Faure, 1999) (Gaspersz, 2001:58-59) (Ismail, 2007:45); penetapan formalisasi atau standarisasi capaian kinerja (Robbins, 1995: 103); perumusan standar dan pedoman kinerja (Mustopadidjaja, 2000:9-10); dan peningkatan kesadaran pegawai akan pelayanan sebagai salah satu prinsip utama dalam penyelenggaraan pemerintahan (Robbins, 1995:4344) (Gaspersz, 2001: 69-70);

Kedua, aspek-aspek dalam iklim organisasi yang memiliki peluang untuk dikembangkan adalah pengembangan sistem rekruitmen dan karir yang didasarkan pada sistem merit (Said, 2007:106-108) melakukan perubahan perilaku dan budaya aparatur yang lebih terbuka dan berorientasi pada nilai-nilai keadilan (Mustopadidjaja, 2000:10); melakukan reformasi birokrasi menuju manajemen modern ( $A$. Kartiwa, 2004:24); mengembangkan birokrasi wirausaha (Said, 2007:320-332).

Ketiga, sementara untuk kapasitas organisasi sesuai dengan pendapat yang diajukan oleh Salusu (2002:303) dan Ansoff dan McDonnell (1990:263) bahwa satuan ukuran yang dapat dipakai untuk mengukur kapasitas organisasi merujuk pada satuan waktu kapasitas kerja dan kebiasaan dalam melakukan pekerjaan yang dikalikan dengan komponen kompetensi pegawai dan iklim organisasi, maka seluruh upaya pada aspek kompetensi pegawai dan iklim organisasi keseluruhannya secara langsung akan memberikan kontribusi dalam upaya peningkatan kapasitas organisasi,

Selain itu dapat dijelaskan bahwa bahwa kapabilitas organisasi UPPD Dinas Pendapatan Propinsi Jawa Barat saat ini masih lemah. Kelemahan kapabilitas atau daya respon internal organisasi jika dianalisis lebih jauh kesemuanya bermuara pada ketidakmampuan organisasi dalam melaksanakan ketentuan formal organisasi untuk berjalan sebagaimana seharusnya sesuai dengan ketentuan yang telah ditetapkan. Hasil survey pendahuluan dan dilanjutkan dengan pengamatan di Pemerintah Daerah menunjukkan bahwa ketetapan organisasi untuk sebagian besar pengelolaan organisasi sudah mampu dirumuskan. Termasuk perumusan tentang standar capaian kinerja, pedoman kerja (SOP) dan sejumlah mekanisme hubungan kerja lainnya. Namun, dalam implementasinya seringkali terjadi penyimpangan yang dipicu oleh kepentingan informal dari sebagian anggota organisasi. Dan yang lebih mengkhawatirkan penyimpangan dari ketentuan ini dilakukan secara kelembagaan artinya dilakukan dengan terbuka, namun dalam proses administrasi pertanggungjawaban kesemuanya dikembalikan seolah-olah itu mengacu kepada ketentuan yang ada.

Munculnya perilaku organisasi yang penuh dengan kepura-puraan, tidak lepas dari dominasi kepentingan informal dalam proses pengambilan keputusan. Kekuasaan dalam proses pengambilan keputusan organisasi lebih banyak bersumber dari kepentingan informal dibandingkan dengan kekuasaan formal atau kewenangan anggota organisasi tersebut.

Proses keorganisasian dan pengambilan keputusan yang tidak didasarkan pada kelembagaan formal telah mereduksi kewenangan jabatan formal yang dimiliki organisasi tersebut. Akibatnya antara 
kewenangan yang dimiliki oleh sebuah jabatan formal tidak sama dengan kekuasaannya. Dengan demikian terjadinya ketidakseimbangan antara kewenangan dan kekuasaan ini diprediksikan sebagai salah satu penyebab lemahnya kapabilitas organisasi.

Kelemahan organisasi pemerintah, baik Pemerintah Pusat maupun Daerah, sebagaimana banyak diungkap oleh para ahli, dapat diidentifikasikan berawal dari ketidakseimbangan antara kewenangan (authority) dan kekuasaan (power) yang dimiliki oleh jabatan formal dalam organisasi tersebut. Dalam banyak hal seringkali proses organisasional tidak disandarkan kepada kewenangan jabatan yang ada, tapi justru pada aspek lain (kekuasaan) di luar kewenangan jabatan formal tersebut. Adanya spoil sistem dan termasuk munculnya korupsi, kolusi dan nepotisme tidak lepas dari tidak seimbangnya kewenangan formal dalam berhadapan dengan kekuasaan yang ada dalam organisasi.

Hasil analisis dan pengamatan menunjukkan bahwa sistem kelembagaan yang ada dalam lembaga pemerintah termasuk di dalamnya UPPD Dinas Pendapatan Propinsi Jawa Barat secara formal telah didesain dalam sistem birokrasi yang modern. Namun kelemahan utamanya adalah dalam pelaksanaannya yang tidak sesuai dengan ketentuan yang ada. Padahal dalam pertanggung jawaban (akuntabilitas) semuanya diarahkan kembali pada ketentuan formal yang ada. Munculnya "tradisi lisan dari birokrasi, suka omongomong dalam seminar tanpa ada keputusan yang konkrit serta tidak ada satu orangpun yang dapat dimintain pertanggungjawabannya" sebagaimana diungkapkan Said (2007:326) dan "kebiasaan birokrasi untuk mengagungkan symbol...telah mendorong kegiatan yang dilakukan asal dilaksanakan" sebagaimana diungkapkan A. Kartiwa
(2004:29) merupakan satu refleksi dari ketiadaan kesebangunan antara kewenangan dan kekuasaan tadi.

Tidak berjalannya aturan dan pedoman kerja yang sudah menjadi ketetapan organisasi, serta terpinggirkan aturan organisasi tersebut oleh kekuasaan yang secara nyata menjadi eksekusi sebuah kebijakan organisasi telah memberikan kontribusi yang cukup nyata dalam menciptakan iklim organisasi yang tidak sehat dan cenderung mengedepankan pendekatan informal dalam keseluruhan proses organisasinya.

Jika mengacu kepada pendekatan siklus kehidupan organisasi dari Robin (Robbins, 1995:7) kondisi organisasi yang belum mampu menjadikan ketentuan dan procedure yang ditetapkan sebagai aturan yang berlaku dalam keseharian organisasi, menunjukkan organisasi tersebut masih 'belum dewasa" atau belum modern.

Indikasi dari kondisi birokrasi Indonesia belum adanya kesebangunan antara kewenangan sebagai cerminan ketentuan formal dengan kekuasaan sebagai cerminan kemampuan informal maka dapat diindikasikan bahwa birokrasi kita masih tradisional. Sebab seharusnya semakin sebangun antara kewenangan dengan kekuasaan dalam proses organisasional menunjukkan semakin modern organisasi tersebut.

Dengan demikian, mengacu kepada hasil penelitian yang dihasilkan dari pembahasan di atas, upaya penataan kapabilitas organisasi baik itu dalam kompetensi pegawai, iklim organisasi dan kapasitas organisasi seharusnya diarahkan kepada pencipatan keseimbangan (balance) antara kewenangan (authority) dan kekuasaan (power) yang dimiliki jabatan dalam organisasi.

Selanjutnya Deddy Mulyadi (2001:27-28) yang mengutip pendapat Newman (1973) yang menggambarkan keduanya dalam skema sebagai berikut:

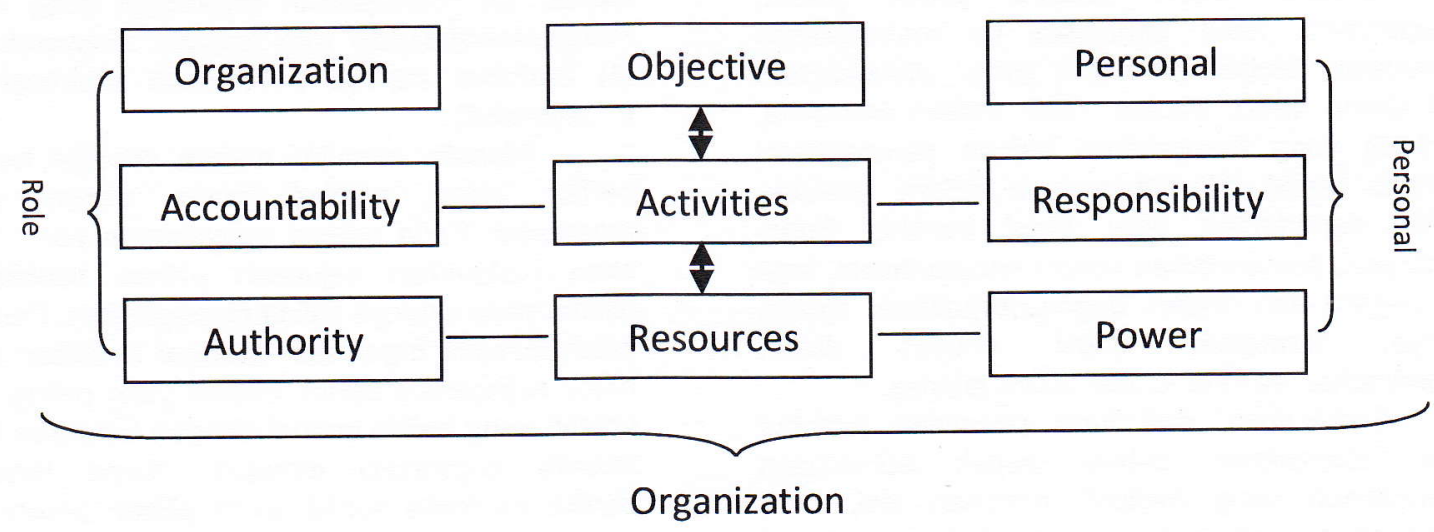

Gambar 3

Kekuasaan - Kewenangan Dalam Organisasi (Newman, 1973) 
Upaya membangun keseimbangan antara kewenangan dan kekuasaan merupakan upaya untuk mengembalikan praktek birokrasi yang cenderung mengalami penyimpangan dari konsep idealnya. A. Kartiwa (2007:3) menjelaskan praktek birokrasi seringkali tidak sejalan dengan pemahaman konsep awalnya. Menurut Schmoller (dalam A. Kartiwa, 2007:3) menyebutkan bahwa birokrsi selalu cenderung ke arah penyimpangan pathologis (masih dapat diobati) dari jalan normal administrasi yang seharusnya. Dan dari tujuh model penyimpangan yang diindikasikan oleh Hiks dan Gulet (dalam A. Kartiwa, 2007:4) tiga diantaranya adalah: (1) munculnya perasaan dalam diri birokrat bahwa memegang suatu jabatan akan memberikan kepemilikan secara pribadi dan hak-hak istimewa lainnya; (2) pengaturan dan pengendalian yang diharapkan merupakan prosedur dalam suatu birokrasi tidak menciptakan manfaat dalam implementasi pekerjaan, serta (3) adanya kekhawatiran atau kecemasan bagi para anggotanya akibat dari perubahan yang dikembangkan, sehingga cenderung tidak mau berubah.

Hasil penelitian ini juga mengindikasikan bahwa keempat dimensi yang membentuk kinerja organisasi dapat ditunjukkan memiliki kemampuan untuk menjelaskan kinerja organisasi. Maka sesuai dengan hasil konfirmasi ini, dapat ditunjukkan bahwa kualitas keseluruhan komponen dari keenam dimensi dalam perencanaan strategis memiliki pengaruh untuk meningkatkan keempat dimensi dari kinerja organisasi.

Kondisi empirik ini sejalan dengan pendapat Greenberg and Baron (2003) yang menyatakan bahwa perencanaan strategis dapat dijadikan pendekatan dalam perubahan perilaku organisasi. Hasil penelitian ini juga sejalan dengan pendapat yang diungkapkan oleh Razik \& Swanson (1995:343) Bryson (2000:14) Mintzberg (1994:28) serta Daneke and Steiss (dalam Sutherland, 1978:428) Hermana (2005) ; Rahayu (2004); Rusyani (2004).

Khusus dalam konteks sektor publik, sebagaimana hasil penelitian ini menunjukkan kesesuaian dengan pendapat yang diungkapkan oleh Quinn 1980; Backer 1980 (dalam Hermana, 2005:53) yang menyatakan bahwa perencanaan strategis dapat diterapkan juga dalam lembaga publik, departemen atau divisi penting dalam organisasi, pemerintahan umum seperti distrik, kota dan negara dan negara bagian, organisasi nirlaba lainnya, termasuk fungsi khusus dalam pemerintahan dan komunitas publik lainnya.

Selanjutnya, dari hasil penelitian tersebut dapat ditunjukkan bahwa aspek perumusan perencanaan yang meliputi rumusan visi, misi, tujuan serta analisis lingkungan eksternal internal serta keterlibatan pimpinan memiliki pengaruh yang paling kecil dibandingkan aspek implementasi strategi yang meliputi penggunaan diagnostik strategis, pilihan pertimbangan, koordinasi, komunikasi dan motivasi dan alokasi sumber daya. Hal ini memberikan gambaran bahwa perencanaan strategis yang ada di UPPD Dinas Pendapatan Propinsi Jawa Barat sesuai dengan apa yang dikhawatirkan oleh Anthony et.al (Dalam Hermana, 2005:52) tentang keterbatasan perencanaan strategis. Menurut Anthony et.al ada kecenderungan bahwa perencanaan strategis hanya akan menjadi "isi formulir", pelaksanaan kegiatan birokrasi dan tidak ada pemikiran strategis di dalamnya. Atau dari Hamel (dalam Usmara, 2006:54) yang mengatakan: "masalah pokok dalam organisasi dewasa ini adalah kegagalan dalam membedakan perencanaan (planning) dengan pembuatan strategi (strategizing)".

Sesuai dengan kondisi ini maka sangat dimungkinkan perencanaan strategis sebagaimana diungkapkan banyak pakar sebagai salah satu pendekatan bahkan ada yang menyebut sebagai "percepatan atau akselerasi" pencapaian tujuan organisasi dengan strategi pencapaiannya yang revolusioner pada lembaga publik masih perlu dioptimalkan. Sebab seharusnya perencanaan strategis menurut Hamel, dalam tulisannya yang dipublikasikan dalam Harvard Business Review bulan Juli-Agustus 1996 (dalam Usmara, 2006:51) sebagai upaya secara revolusioner dalam pembuatan sebuah strategi pengembangan perusahaan. Lebih jauh Hamel menyatakan perencanaan adalah pembuatan program untuk para teknokrat dan memberikan tanggung jawab kepada perencana untuk membuat strategi adalah sama halnya dengan meminta tukang batu untuk membuat patung yang indah.

Gagasan tentang upaya untuk mengoptimalkan pencapaian kinerja organisasi publik melalui perencanaan strategis diungkapkan juga oleh Bennett (dalam Salusu, 1996:40) yang memberikan argumentasi bahwa organisasi nonprofit seperti organisasi publik dapat dibangkitkan semangatnya melalui perencanaan strategis.

Sementara Kotler (dalam Salusu, 1996:41) menawarkan petunjuk untuk upaya tersebut, yaitu melalui: (1) pengembangan misi organisasi yang jelas; (2) mengidentifikasi kepentingan publik yang utama; (3) menciptakan organisasi yang mampu mengkomunikasikan misi kepada masyarakat dan (4) berfokus kepada penciptaan kepuasan klien (masyarakat).

Filosofis memiliki makna sebagai landasan berfikir untuk melihat masa depan sebuah organisasi. Pada proses penyusunan perencanaan akan melahirkan sejumlah pilihan bahkan ada pilihan yang sifatnya saling menegasikan. Pada saat itulah filosofis organisasi sebagai landasan berfikir harus mengambil peran. Pilihan yang paling sesuai adalah yang paling sesuai dengan landasan berfikir filosofis organisasi tersebut. Tanpa lanadasan berfikir ini maka konflik akan pilihan perencanaan akan terus berkembang dengan tidak menemukan jalan pemecahannya.

Sesuai dengan pembahasan di atas maka perencanaan strategis tidaklah seharusnya menggantikan konsep perencanaan secara keseluruhan. Perencanaan strategi fokus pada aspek - aspek strategis dalam pencapaian tujuan 
organisasi. Rumusan visi dan misi seharusnya menjadi acuan dalam pemetaan kekuatan internal dan eksternal organisasi. Hasil dari perencanaan strategis akan mampu menempatkan organisasi publik dalam kemampuan optimalnya dalam memberikan layanan kepada masyarakat.

Selanjutnya, sesuai dengan hasil analisis pengaruh perencanaan strategis dengan keenam dimensinya terhadap pencapaian kinerja organisasi, maka dapat dirumuskan bahwa melalui perencanaan strategis ini organisasi publik dapat dengan jelas memilih strategi operasi organisasi dengan berbasis efisiensi atau efektifitas. Jika berbasis efisiensi artinya organisasi menetapkan terlebih dahulu tujuan yang ingin dicapai, baru pada tahap selanjutnya melakukan analisis pembiayaan yang paling minimum untuk mencapai tujuan tersebut, Atau sebaliknya justru memilih strategi yang berbasis efektivitas, yaitu menganalisis sumber daya yang dimiliki organisasi, baru melakukan strategi pengembangan yang paling optimal dari sumber daya yang tersedia tersebut. Dengan strategi yang tepat maka diharapkan pelayanan prima yang seharusnya diberikan oleh organisasi publik dapat tercapai. Atau dalam kata lain organisasi melalui perencanaan strategis seharusnya mampu mendorong organisasi untuk memiliki daya saing (competitive advantage) yang jelas (Hitt, et.al, 2001:3).

Kedua dasar acuan dalam penetapan strategi ini lebih sesuai dengan kondisi institusi publik yang pola pembiayaannya berbasis anggaran publik. Dimana proses penetapan anggaran pendapatan dan belanja juga melibatkan lembaga legislatif. Melalui pendekatan penyusunan strategi yang berbasis prinsip efisiensi dan efektivitas akan melahirkan dimungkinkan akan memberikan kemudahan kepada satuan kerja di instansi pemerintah dalam menentukan capaian kinerja kegiatan berikut capaian sasarannya. Selain itu penetapan capaian kinerja yang berbasis efektivitas dan efisiensi saat ini sesuai dengan pendekatan pengukuran dalam system akuntabilitas instansi pemerintah yang saat ini berlaku.

Perencanaan strategis itu sendiri harus difahami sebagai pendekatan (approach) yang dapat dikembangkan organisasi dalam menyusun strategi. Perencanaan strategis tidak menggantikan fungsi organisasi dan elemen organisasi. Perencanaan strategis justru menjadi instrument atau media untuk memadukan seluruh elemen organisasi dan fungsi organisasi. Strategi yang dikembangkan dapat didasarkan pada prinsip efisiensi dan efekstivitas. Pilihan strategis akan sangat menentukan saya saing organisasi dalam mencapai tujuan organisasi, yang dalam hal tertentu diukur melalui capaian kinerja organisasi.

Selanjutnya, dari hasil penelitian ini juga dapat digambarkan bahwa pengukuran kinerja yang dilakukan sesuai dengan yang dikonsepsikan oleh Withaker (1995:36) yaitu sebagai alat manajemen yang dipergunakan dalam meningkatkan kualitas pengambilan keputusan serta sekaligus akuntabilitas untuk menilai keberhasilan atau kegagalan pelaksanaan kegiatan dan program sesuai dengan sasaran dan tujuan yang telah ditetapkan.

Hasil penelitian memberikan indikasi bahwa kinerja kelembagaan publik masih lebih banyak direpresentasikan melalui perspektif keuangan. Sementara pengukuran kinerja organisasi yang berkaitan dengan proses keorganisasian atau internal proses yang meliputi proses inovasi dan pengukuran efisiensi dan efektivitas operasi masih kurang memadai. Bahkan untuk perspektif kepuasan masyarakat sebagai penerima layanan publik serta pembelajaran dan pertumbuhan organisasi masih termasuk tidak memadai.

Hasil penelitian tentang kinerja organisasi yang masih belum memadai dalam perspektif konsumen dan pembelajaran dan pertumbuhan organisasi ini sekaligus sejalan dengan kurang memadainya proses perencanaan strategis dalam dimensi-dimensi yang berkaitan dengan aspek implementasi strategi itu sendiri.

Untuk tantangan bagi organisasi publik saat ini ke depan adalah menjadikan indikator-indikator capaian kinerjanya tidak terbatas pada indikator yang ada pada perspektif keuangan semata. Namun, juga harus mulai menjadikan indikator lain seperti indikator kepuasan pelanggan sebagai salah satu atau bahkan indikasi utama kinerja organisasinya (Kasali, 20067:154), selain indikator kepuasan pegawai dan peningkatan pembelajaran dan pertumbuhan organisasi itu sendiri.

Pandangan Kaplan dan Norton (2000) tentang empat perspektif pengukuran kinerja organisasi yang sebelumnya diperuntukan untuk sektor bisnis dipandang memiliki ketepatan untuk dipergunakan pada sector publik. Kesimpulan ini merupakan penguatan atas pendapat Suharyani (dalam Natsir, dkk, 2003:38) (Imelda, 2007:107) yang secara tegas menyebutkan bahwa pendekatan balance scorecard ini merupakan metode yang dipandangnya untuk saat ini paling komprehensif sebagai metode pengukuran kinerja organisasi publik baik dari sisi keuangan maupun nonkeuangan. Hal ini memiliki relevansi dengan pengukuran kinerja lembaga publik yang juga harus memberikan pertanggungjawaban kepada seluruh stakeholders (Hatry dalam Natsir, dkk, 2003:37).

Selain itu, secara khusus dalam kontek pengukuran kinerja pemungutan pajak dan khususnya pemungutan PKB \& BBNKB yang selama ini dipergunakan adalah membandingkan antara target yang telah ditetapkan pada awal tahun dengan realisasi penerimaan pada akhir tahun. Dan hal ini jika dianalisis lebih mendalam konsep pengukuran kinerja ini memiliki sejumlah kelemahan. Pertama, Penetapan Target dilakukan dengan menggunakan asumsi pertumbuhan faktorfaktor yang membentuk target tersebut adalah cenderung linier, artinya tidak ada kebijakan ataupun kejadian yang sifatnya luar biasa. Dengan demikian permodelan secara ekonomi hal ini dapat dilakukan. Kedua, tingkat realisasi penerimaan yang masuk, khususnya wajib pajak yang melakukan daftar ulang atau registrasi merupakan bagian yang tidak sepenuhnya dalam kendali lembaga 
pemungut, dalam hal ini UPPD Dinas Pendapatan Propinsi Jawa Barat.

Untuk itu, maka sebaiknya penetapan target dan potensi pada awal diperuntukan hanya sebagai acuan sementara saja, sementara pengukuran kinerja sebaiknya menggunakan perbandingan antara realisasi penerimaan dengan potensi real tahun tersebut. Jadi pada akhir tahun seharusnya dihitung potensi berdasarkan faktor-faktor yang sudah ditetapkan sebagai dasar perhitungan potensi $\mathrm{PKB}$ \& BBNKB, lalu dibandingkan tingkat realisasinya.

Melalui pendekatan ini, maka diharapkan pengukuran kinerja lembaga pemungut $\mathrm{PKB}$ \& BBKB memiliki landasan yang lebih kuat untuk ditentukan kriteria keberhasilannya. Dan jika memungkinkan unit yang melakukan perhitungan potensi real PKB \& BBNKB adalah unit yang terpisah dari unit UPPD Dinas Pendapatan Propinsi Jawa Barat, namun masih dalam kelembagaan Dinas Pendapatan Propinsi Jawa Barat, misalnya di Sub Dinas Pengendalian Program.

Keuntungan yang dapat diperoleh dari penetapan kinerja pemungutan PKB \& BBNKB seperti yang diusulkan di atas adalah menghilangkan terjadinya penetapan target yang kurang dari potensi. Keuntungan berikutnya, dengan adanya perhitungan potensi real ini yang sebaiknya juga diuji dan di publikasikan kepada publik akan mendorong terciptanya akuntabilitas pemungutan pajak daerah secara keseluruhan.

\section{Simpulan dan Saran}

Merujuk pada hasil analisis, pengujian hipotesis, pembahasan serta temuan penelitian, dapat dikemukakan kesimpulan sebagai berikut:

a. Peningkatan perencanaan strategis melalui peningkatan kompetensi pegawai, iklim organisasi dan kapasitas organisasi secara signifikan berpengaruh terhadap peningkatan kinerja organisasi UPPD Dinas Pendapatan Propinsi Jawa Barat.

b. Dimensi-dimensi iklim organisasi memiliki pengaruh lebih besar terhadap perencanaan strategis dibandingkan dimensi-dimensi dari kompetensi pegawai dan kapasitas organisasi.

c. Konsep baru yang dapat diangkat dari hasil penelitian ini adalah peningkatan kinerja organisasi publik melalui perencanaan strategis dilakukan melalui lima hal, yaitu: (1) melakukan transformasi birokrasi melalui membangun keseimbangan antara kewenangan dengan kekuasaan pada aspek kapabilitas organisasi baik itu kompetensi pegawai, iklim organisasi maupun kapasitas organisasi; (2) membangun fungsi perencanaan strategis sebagai proses percepatan (akselerator) dan sekaligus instrumen perubahan perilaku dalam pencapaian visi dan misi organisasi; (3) membangun dasar perumusan strategi dan implementasinya yang berbasis efisiensi dan efektivitas; (4) membangun pendekatan pengukuran kinerja organisasi yang lebih komprehensif, yaitu persfektif keuangan, proses keorganisasian, kepuasan masyarakat serta pembelajaran dan pertumbuhan organisasi; (5) membangun model pengukuran kinerja pemungutan pajak dengan menggunakan formulasi perbandingan antara realisasi dengan potensi ril pada tahun yang bersangkutan.

Dari kesimpulan di atas penulis menyarankan :

a. Kajian ini telah menunjukkan bahwa dimensidimensi dari iklim organisasi memiliki pengaruh lebih besar terhadap perencanaan strategis, dibandingkan dengan dimensidimensi dari kompetensi pegawai dan kapasitas organisasi. Untuk itu diperlukan kajian lebih lanjut yang membahas tentang faktor-faktor yang menjadi penyebab kuatnya faktor iklim organisasi ini. Studi ini akan memberikan manfaat untuk mendapatkan kejelasan sekaligus penyempurnaan model peningkatan kapabilitas organisasi terhadap perencanaan strategis dalam meningkatkan kinerja organisasi.

b. Kajian ini menempatkan variabel perencanaan strategis sebagai satu variabel yang utuh antara perumusan strategi dan implementasi strategi. Hasil studi menunjukkan ada perbedaan perilaku responden dalam perumusan strategi dan implementasi strategi. Untuk itu disarankan dalam kajian lebih lanjut untuk memisahkan kedua fungsi perumusan strategi dan implementasi strategi ini.

c. Kajian ini juga baru berhasil menganalisis konsep perencanaan strategis dari pendekatan proses penyusunan perencanaan strategis. Namun belum mampu menyentuh aspek yang berkaitan dengan ketepatan dalam pengambilan keputusan dalam melakukan pilihan strategi sebagai hasil dari proses perencanaan strategis. Untuk itu, disarankan dalam kajian lebih lanjut untuk mengkaji perencanaan strategis dari ketepatan dalam melakukan pilihan strategi dan hubunganya dengan posisi daya saing organisasi dalam mencapai visi dan misi organisasi.

d. Perlu dikembangkannya model pengukuran kinerja pemungutan pajak dengan menggunakan formulasi perbandingan antara realisasi dengan potensi real pada tahun yang bersangkutan. Tingginya dimensi pada aspek implementasi strategi dibandingkan dengan perumusan memberikan dasar untuk mendorong penciptaan dan sekaligus pemahaman ulang tentang perencanaan strategis. Sosialisasi dan lokakarya yang lebih menekankan pada upaya pemahaman tentang pentingnya perencanaan strategis sebagai instrumen perubahan perilaku sehingga mampu mendorong organisasi mencapai pelayanan terbaiknya harus terus diupayakan. Penelitian ini memiliki keterbatasan dalam penentuan jumlah luasan 
cakupan penelitian, untuk itu agar mampu memberikan penjelasan yang lebih terhadap fenomena yang diteliti dapat dilakukan penelitian yang mencakup lokus studi yang lebih luas unit yang sama pada beberapa daerah atau pada seluruh SKPD yang ada di suatu daerah. Atau bahkan dilakukan studi atas fenomena yang diteliti dengan mengkomparasi antara sektor publik dan sektor swasta.

\section{DAFTAR PUSTAKA}

Ansoff, H. Igor and McDonnell, Edward J, 1990, Implanting Strategic Management, Second Edition, Prentice Hall, London

Bergenhenegouern, G. J., 1997, "Competence Development: A Challenge for Human Resources Professionals: Core Competences of Organizations as Guideliness for the Development of Employees, Industrial and Commercial Training, Vol. 29, No. 2, hal. 5562

Bolger, Joe, 2000, Capacity Development, why, what and how, Jurnal CIDA Policy Branch Vo. 1 No. 1 May 2000.

Cummings \& Worley, 2001, Organization Development \& Change, Seventh Edition, South-Western College, Ohio, USA

Davis, Keith and Newstrom, John W., 1985, Human Behavior At Work, Organizational Behavior, McGraw-Hill, Inc.

DuBrint, Andrew J., 1984, Foundation of Organization Behavior, Prentice Hall, New Jersey

Faure, Lesley Munro and Faure Malcolm Munro, 1999, Implementing Total Quality Management, menerapkan manajemen mutu terpadu, PT Elex Media Komputindo, Gramedia, Jakarta

Fletcher, C. and William, R., 1985, Performance Appraisal and Career Development, London: Hutchinson.

George, Jennifer M., \& Jones, Gareth R., 2002, Organizational Behavior, Third Edition, Pearson Education Inc. New Jersey, USA

Gerungan, WA., 1988, Psikologi Sosial, PT. Eresco, Bandung.

Greenberg, Jerald \& Baron, Robert. A., 2003, Behavior in Organizations, Eight Edition, Pearson Education Inc. New Jersey, USA.

Hellriegel, Don, \& Slocum, John W., 2004, Organizational Behavior, Tenth Edition, South-Western, Canada

Hersey, Paul., \& Blanchard, Kenneth, 1980, Management of Organizational Behavior, New Delhi: Prentice Hall of India.

Imelda, RHN, 2007, Implementasi Balanced Scorecard pada Organisasi Publik, Simposium Nasional Akuntansi X, Makasar, 26-27 Juli 2007

Jo-Hatch, Mary, 1997, Organization Theory: Modern Symbolic and Postmodern Perspectives, Oxford University Press, Oxford, UK
Kaplan, R.S. \& Norton, D.P., 1996. Balanced Scorecard Translating Strategy Into Action. Boston: Harvard Business School Press.

Leemans, Arne F., 1976, The Management of Change in Govemment, Martinus Nijhoff, The Hague Netherland.

Leonard, Goodstein D., and Timothy M Nolan, Pfeiffer J William, 1993, Applied Strategic Planning, McGraw-Hill, New York USA.

Luthans, Fred, 1985, Organizational Behavior, McGraw-Hill, NY USA

Mintzberg, Henry, 1994, The Rise and Fall of Strategic Planning, The Free Press, a Division of Mcmilan Inc. NY USA.

Morisawa, Toru, 2002, Building Performance Measurement Systems With Balanced Scorecard Approach, Nomura Research Institut, Papers No. 45 April $1^{\text {st }}, 2002$

Mulyadi, 2001, Balanced Scorecard Alat Manajemen Kontemporer Untuk Pelipatganda Kinerja Keuangan Perusahaan. Jakarta: Salemba Empat.

Nasir, Safar, dkk,, 2003, Pengukuran Kinerja Pemerintah Daerah (penyunting), FE UAD, BPK, Partnership For Governance Reform in Indonesia dan UAD Press., Jakarta.

Osborne D, and Gaebler T., 1992, Reinventing Government, Reading MA, Addison Wesley Longman Inc.

Pierce, Jon L., \& Gardner, Donald G., 2002, Management and Organizational Behavior: an Integrated Perspective, South-Western, Ohio, USA

Pietersen, Willie, 2002, Reinventing Strategy, using strategic learning to create and sustain breaktrough performance, John Wiley \& Sons Inc. New York USA.

Poole, Marshal Scott, and Robert D. McPhee, 1985, Communication Climate and Organizational: Review, Critique an a new Perspektif, Beverly Hills Calf Sage Publication

Pyzdek., 2000, A Six Sigma Handbook. Jakarta: Salemba Empat.

Razik \& Swanson, 1995, Fundamental Concept of Educational Leadership and Management. New Jersey: Prentice Hall.

Robbins, Stephen P., \& Barnwell, Neil, 2002, Organization Theory: Concept and Cases, Fourth Edition, Prentice Hall, New Jersey, USA

Rohdewohld, Rainer, 1995, Public Administration in Indonesia, Motech PTY, Ltd., Melbourne, Victoria, Australia

Rowe, A. , et al. , 1995, Strategic Management: Concept and Application. San Francisco: Jossey-Bass Publishers.

Sackman Sonja, 1989, The Role of Metaphors in Organization Transformation, Human Relation, Calf Sage Publication,

Saefullah, A. Djadja, 2007, Semerbak Senjakala, Biografi \& Jejak Pemikiran, Yayasan Bina Profesi, Bandung.

Shafritz, Jay M., \& Russel, E.W., 1997, Introducing Public Administration, Longman, New York 
Sofo, Francesco, 1999, Human Resource Development, Perspective, Roles and Practice Choices. Warriewood, NSW: Business and Professional Publishing.

Steers, Richard M, 1980, Motivation and Work Behavior. New York: McGraw-Hill Series.

Steiner, G.A., 1979, Strategic Planning: What Every Manager Must Know. New York: The Free Press.
Sweeney, Paul D., \& McFarlin, Dean B., 2002, Organizational Behavior: Solutions For Management, The McGraw-Hill Companies Inc., New York, USA

Ulrich, Dave, 1998, Delivering Result: A New Mandate for Human Resource Proffesional. Boston, Harvard Business School Press.

Wheelen Thomas L, and Hunger, J David, 1999, Strategic Management and Business Policy, Prentice Hall, New Jersey USA. 